\title{
Correction: Sodium-glucose co-transporter 2 inhibitor therapy: mechanisms of action in heart failure
}

Joshi SS, Singh T, Newby DE, et al. Sodium-glucose co-transporter 2 inhibitor therapy: mechanisms of action in heart failure. Heart 2021;107:1032-1038. doi:10.1136/heartjnl-2020-318060

This article has been corrected since it was first published. The provenance and peer review statement has been included.

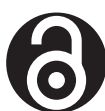

\section{OPEN ACCESS}

Open access This is an open access article distributed in accordance with the Creative Commons Attribution 4.0 Unported (CC BY 4.0) license, which permits others to copy, redistribute, remix, transform and build upon this work for any purpose, provided the original work is properly cited, a link to the licence is given, and indication of whether changes were made. See: https:// creativecommons.org/licenses/by/4.0/.

(c) Author(s) (or their employer(s)) 2021. Re-use permitted under CC BY. Published by BMJ.

Heart 2021;107:e15. doi:10.1136/heartjnl-2020-318060corr1

(D) Check for updates 